\title{
Lífsgæði eftir ristilbrottnám vegna sáraristilbólgu
}

\author{
Katrín Guolaugsdóttir ${ }^{1}$, Elsa B. Valsdóttir ${ }^{1,2}$, Tryggvi B. Stefánsson ${ }^{1}$ \\ Höfundar eru öll læknar
}

\section{Á G R I P}

Tilgangur: Pónokkur hluti sjúklinga með sáraristilbólgu fer i ristilbrottnám. Markmið rannsóknarinnar var að kanna lífsgæði pessara sjúklinga eftir aðgerð.

Efniviður og aðferðir: Allir sjúklingar með sáraristilbólgu sem fóru i ristilbrottnám á Landspítala eđa Sjúkrahúsi Akureyrar á árunum 1995-2009 og voru á lífi i upphafi rannsóknar voru i úrtakinu. 106 sjúklingar fengu senda prjá spurningalista. SF-36v2 og EORCT QLQ-CR29 eru staðlaðir lífsgæðalistar par sem spurt er um almennt viðhorf til heilsu og um einkenni frá endaparmi eđa stóma. Priðji listinn innihélt starfrænar spurningar hannaðar af rannsóknaraðilum.

Niðurstöður: Svör bárust frá 83 (78\%), 45 körlum (54\%) og 38 konum (46\%). Meðalaldur við aðgerð var 45 ár (10-91 ár). Fjörutíu og fjórir (53\%) höfðu garnarauf, 28 (34\%) innri garnapoka (IPAA) og 11 (13\%) tengingu mjógirnis í endaparm. Hjá sjúklingum par sem endaparmur var fjarlægður lýstu 37\% breytingum á pvaglátum og $46 \%$ á kynlífi eftir aðgerð. $75 \%$ svarenda með innri garnapoka lýstu hægðaleka en hann var vægur samkvæmt Wexner-skala hjá 83\% peirra. Enginn munur var á lífsgæðum pátttakenda og almenns pýðis samkvæmt SF-36v2. Sjúklingar höfðu litlar áhyggjur af heilsu, líkamsímynd eða pyngd og höfðu aðeins mild einkenni samkvæmt EORTC QLQ-CR29.

Ályktanir: Algengt var að breytingar yrðu á pvaglátum og kynlífi eftir aðgerð pegar endaparmur var fjarlægður. Hægðaleki hjá peim sem fengu innri garnapoka virtist mun algengari en búist var við. Ekki var marktækur munur á lífsgæðum peirra sem höfðu farið í aðgerð og almenns pýðis. Niðurstöđur rannsóknarinnar eru mikilvægar pegar verið er að upplýsa sjúklinga um aðgerðarmöguleika par sem brottnám á ristli eða pað að hafa stóma virðist ekki skerða lífsgæði.

\section{Inngangur}

Nýgengi sáraristilbólgu hefur aukist stöðugt á Íslandi frá 1950 til 2009. Nýgengið var 7,4 á tímabilinu 1950-1979,1 11,7 1980-1989,2 16,6 1990-1994³ og 20,4 1995-2009. ${ }^{4}$ Fyrir tímabilið 2005-2009 var nýgengið $22,1 .^{4}$

Brottnám á ristli og endaparmi er mikilvægur páttur í meðferð á sáraristilbólgu. Ábendingar fyrir bráđaaðgerð eru oftast bráð ristilbólga sem ekki ræðst við með lyfjum og sjaldnar rof á ristli eða blæðingar. Ábendingar fyrir valaðgerðum eru skortur á svörun við lyfjameðferð, krabbamein eða krabbameinsáhætta, prenging á görn, fylgisjúkdómar utan garnarinnar og pegar börn prífast ekki., Líkur á pörf fyrir ristilbrottnám eru 31\% lægri meðal peirra sem hafa verið meðhöndlaðir með infliximab en með cyclosporíni. Hlutfall sjúklinga sem fer í ristilbrottnám er hærra í fyrsta „kasti“ en síðari „,köstum“ (17,2\% á móti 10,6\%). Alvarleiki ristilbólgu og aldur eru mikilvægir forspárpættir fyrir ristilbrottnám.? Hlutfall sjúklinga með sáraristilbólgu sem parf á aðgerð að halda einu, 5 og 10 árum eftir greiningu var 4,9\%, 11,6\% og 15,6\% árin 1955-70 og hefur farið lækkandi síðustu 6 áratugi. Meðal sjúklinga sem greindust árin 2000-2010 var hlutfallið eftir eitt og 5 ár

${ }^{1}$ Skurðdeild Landspítala, ${ }^{2}$ æknadeild Háskóla Íslands.

Fyrirspurnum svarar Elsa B. Valsdóttir, elsava@landspitali.is

Höfundar hafa útfyllt eyðublað um hagsmunatengsl.

https://doi.org/10.17992//bl.2016.11.105

Greinin barst 19. janúar 2016, sampykkt til birtingar 22. september 2016.
2,3\% og 7,6\%. ${ }^{8}$ Aðalaðgerðin vegna sáraristilbólgu er brottnám á ristli og endaparmi með endagarnarauf. Stómapokinn getur verið ópægilegur og hindrað pá sem purfa að hafa hann. Breytingar á meðferðinni hafa pví miðast við pað að losa sjúklinga við stómapokann. Ef endaparmurinn er ekki sjúkur er hægt að skilja hann eftir og tengja smáparminn í efsta hluta endaparmsins. ${ }^{9}$ Árið 1971 gerðu Parks og Nichols innri garnapoka (ileal pouch-anal anastomosis, IPAA) sem peir tengdu niður í endaparmsopið..$^{10}$ Við pá tegund aðgerðar er oft útbúin tímabundin garnarauf (covering loop ileostomy) sem síðar er sökkt.

Nýgengi parmabólgusjúkdóma í vestrænum löndum hefur ver¡ð að aukast frá pví um miðja 20. öld og aukningin virðist tengjast umhverfispáttum. ${ }^{11}$ Pó liggja ekki fyrir nákvæmlega hvaða pættir í umhverfinu (lífsstíll, mataræði, aukið hreinlæti eða annað) tengjast próun sjúkdómanna. ${ }^{12}$ Pó miklar framfarir hafi orðið í lyfjameðferð parmabólgusjúkdóma undanfarin ár er alltaf stór hluti sjúklinga sem á endanum parf á aðgerð að halda.

Lífsgæði sjúklinga með alvarlega sáraristilbólgu batna umtalsvert eftir brottnám á ristli og samsvara jafnvel lífsgæðum almenns pýðis í erlendum rannsóknum. ${ }^{13,14}$ Lífsgæði sjúkinga með garnarauf og innri garnapoka eru svipuð. ${ }^{15-17}$ Tilgangur rannsóknarinnar var að meta árangur aðgerða hjá peim sem fóru í brottnám á ristli og endaparmi vegna sáraristilbólgu á Íslandi 1995-2009 með tveimur lífsgæðaprófum SF-36v2 (Short Form (36) Health Survey) og EORTC QLQ-CR29 (European Organization for Research and Treatment of Cancer Quality of Life Questionnaire - Colorectal 29) og spurningalista sem var hannaður af rannsakendum sjálfum. 


\section{Efniviður og aðferðir}

Pátttakendur voru allir sjúklingar með sáraristilbólgu sem fóru í ristilbrottnám á Landspítala eða Sjúkrahúsinu á Akureyri á árunum 1995-2009 og voru á lífi í upphafi rannsóknar. Á pessu tímabili greindust 884 einstaklingar með sáraristilbólgu á Íslandi. ${ }^{4} \mathrm{Upp}$ lýsingar um hvaða sjúklingar fóru í ristilbrottnám 1995 til 2009 voru fengnar frá rannsóknarstofu Háskólans í meinafræði og frá meinafræðideild Sjúkrahússins á Akureyri. Nánari upplýsingar um greiningu, aðgerð og afdrif sjúklinganna voru fengnar úr sjúkraskrám. Aðgerð var skilgreind sem bráðaaðgerð ef hún var skilgreind pannig í aðgerðarlýsingu eða af svæfingarblaði. Prálát bráð einkenni eru svæsin einkenni sem lagast ekki við lyfjameðferð. Prálát langvinn einkenni eru einkenni sem hægt er að halda að einhverju leyti niðri með lyfjum en sjúklingurinn verður aldrei einkennalaus eða ekki hægt að taka hann af sterameðferð. Dreifing sjúkdómsins var fengin frá meinafræðisvörum og var skilgreind sem bólga í vinstri hluta ristils ef bólgan var neðan við miltisbeygju og víðtæk, (umfangsmikil, meiriháttar) ef hún náði upp fyrir miltisbeygju. Prjár tegundir aðgerða voru framkvæmdar: 1) Tenging innri garnapoka við endaparm (Ileal pouch-anal anastomosis, eða IPAA), oft með tímabundinni garnarauf (covering loop ileostomy); 2) Tenging smágirnis við endaparm (Ileorectal anastomosis, eða IRA); 3) Garnarauf (end ileostomy, eða EI). Innri garnatenging var skilgreind sem tenging smágirnis í endaparm (IRA) eða innri garnapoki (IPAA). Fundinn var meðalaldur sjúklinga við aðgerð og einnig meðalaldur pegar rannsóknin var gerð (2011). Hundrað og sex sjúklingar fengu senda prjá spurningalista. Send var út ein ítrekun til 60 sjúklinga og síðan hringt einu sinni í pá sem enn höfðu ekki svarað.

Fyrsti listinn innihélt að mestu leyti starfrænar spurningar hannaðar af rannsóknaraðilum. Listinn var í fjórum hlutum. Fyrsti hlutinn var um pvaglát og kynlíf. Annar hlutinn var um hægðaleka (mælt með Wexner-skala par sem 5 breytur eru metnar á bilinu 0 (aldrei) til 4 (daglega) hvað varðar tíðni leka á lofti, vökva, formuðum hægðum, notkun innleggs, og breytingar á lífsstíl) og hægðalosunarvandamál. Í priðja hlutanum var spurt um vandamál af garnaraufinni. Í fjórða hluta var spurt almennt um meðferðina og fjarveru frá vinnu fyrir og eftir aðgerðirnar.

SF-36v2-listinn inniheldur spurningar um almennt viðhorf til heilsu og metur bæði líkamlega og andlega pætti. Spurningar listans má flokka í 8 undirflokka, fjóra líkamlega og fjóra andlega. Peir eru eftirfarandi: Líkamleg virkni (physical functioning), líkamlegt hlutverk (physical role), líkamlegur verkur (bodily pain), almenn heilsa (general health), lífsneisti (vitality), félagsleg virkni (social function), tilfinningalegt hlutverk (emotional role) og andleg heilsa (mental health). Niðurstöðurnar eru dregnar saman í tvö tölugildi (score), heildartölugildi fyrir líkamlega pætti (physical component score) og heildartölugildi fyrir andlega pætti (mental component score). Hærra tölugildi pýðir meiri lífsgæði, lægra gildi pýðir minni lífsgæði. Svör sjúklinga voru sett inn í forrit (Quality Metric Health Outcomes ${ }^{\mathrm{TM}}$ Scoring Software 4.0) sem vann úr niðurstöðunum og bar pær saman við almennt bandarískt pýði. Niðurstöðurnar voru svo skoðaðar út frá kyni, tegund aðgerðar og aldurshópi.

EORTC QLQ-CR29 er spurningalisti sem mælir sjúkdómstengd lífsgæði. ${ }^{18}$ Hann, líkt og aðrir EORTC-spurningalistar, var hannaður fyrir sjúklinga með krabbamein en pessir spurningalistar hafa einnig verið notaðir til að meta lífsgæði sjúklinga með góðkynja sjúkdóma. ${ }^{19}$ Listinn inniheldur 29 atriði sem má flokka í fjóra virkniskala (líkamsímynd, kvíði, pyngd og áhugi á kynlífi) og 18 einkennisskala (pvagfæraeinkenni, gerð hægða, meltingareinkenni, verkir og önnur einkenni) Álitið er að pví sterkari sem einkenni eru, peim mum minni séu lífsgæðin. Spurningar varðandi meltingareinkenni eru mismunandi fyrir sjúklinga með og án garnaraufar. Vandamál tengd kynlífi eru metin á mismunandi hátt fyrir konur og karla og notast við mismunandi spurningar fyrir hvort kyn. Tölugildin sem gefin eru eru milli 0 og 100. Fyrir lífsgæði í almenna lífsgæða- og virkniskalanum pýðir hærra gildi meiri lífsgæði. Fyrir einkennaskalana pýðir hærra gildi verri/ meiri einkenni. Leyfi fyrir notkun listans var fengið hjá útgefendum hans. Spurningalistarnir prír eru birtir við greinina á heimasíðu blaðsins.

Leyfi fyrir rannsókninni fengust frá Vísindasiðanefnd (VSNb2011010001/03.1) og Persónuvernd (S5440/2011).

Tölfræði er fyrst og fremst lýsandi. Forritið sem notað var við úrvinnslu SF-36v2 gefur upp meðaltöl með staðalfráviki og við miðum við að munur sé ekki marktækur ef hann er minni en eitt staðalfrávik. Úrvinnsla EORTC-listans var framkvæmd með Excel með miðgildi og fjórðungaspönn (interquartile range).

\section{Niðurstöður}

\section{Almennt}

Alls fundust 118 sem höfðu farið í ristilbrottnám vegna sáraristilbólgu á Íslandi á árunum 1995 til 2009. Fimmtíu og fimm fóru í bráðaaðgerð (47 á Landspítala og 8 á Sjúkrahúsinu á Akureyri) og 63 í valaðgerð (62 á Landspítala og einn á Sjúkrahúsinu á Akureyri). Við upphaf rannsóknar höfðu 7 sjúklinganna látist, tveir sjúklingar voru með krabbamein og prír voru búsettir erlendis og voru pví útilokaðir (mynd 1). Ábendingar fyrir aðgerð hjá peim 106 sem eftir voru, voru prálát bráð sáraristilbólga ( $\mathrm{n}=91)$ og prálát krónísk sáraristilbólga $(\mathrm{n}=15)$, pað fór enginn í aðgerð vegna bólgu í endaparmi eingöngu. Tuttugu og prír sjúklingar höfðu „colitis sin“ (E2) og 83 höfðu víðtæka ristilbólgu (extensive colitis) (E3) samkvæmt Montreal-skala. Pað fóru allir í aðgerð vegna missvæsinna einkenna en engin aðgerð var gerð hjá einkennalausum einstaklingi vegna pess að hann væri búinn að vera lengi (>10 ár) með sjúkdóminn.

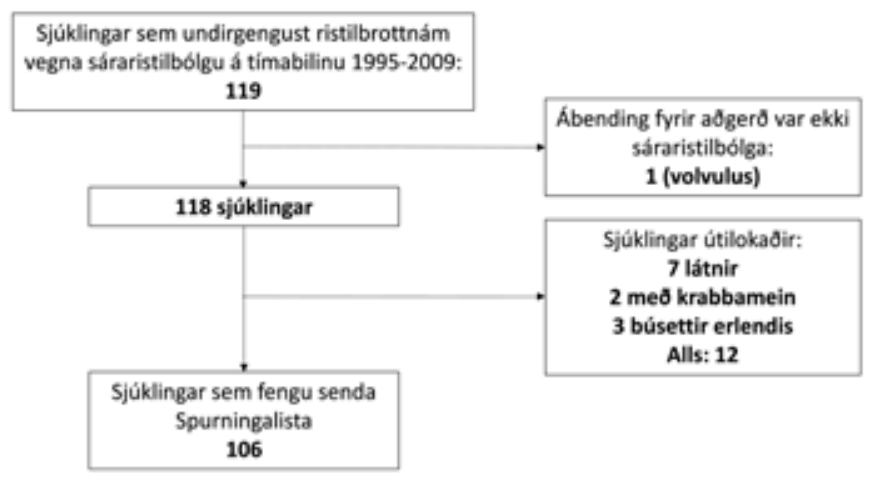

Mynd 1. Sjúklingar sem fengu senda spurningalista. 
Tafla I. Meðalaldur sjúklinga við aðgerð og við rannsókn (2011).

\begin{tabular}{lccc}
\hline Sjúklingahópur & $\begin{array}{c}\text { Fjöldi } \\
\text { svarenda }\end{array}$ & $\begin{array}{c}\text { Meðalaldur } \\
\text { við aðgerð } \\
( \pm \text { staðalfrávik) }\end{array}$ & $\begin{array}{c}\text { Meðalaldur við } \\
\text { rannsókn (2011) } \\
( \pm \text { staðalfrávik) }\end{array}$ \\
\hline Allir & 83 & $44( \pm 16)$ & $53( \pm 17)$ \\
\hline El $^{\star}$ & 44 & $50( \pm 15)$ & $59( \pm 15)$ \\
\hline IRA & 11 & $45( \pm 18)$ & $53( \pm 19)$ \\
\hline IPAA $^{* *}$ & 28 & $35( \pm 13)$ & $44( \pm 13)$ \\
\hline
\end{tabular}

$\mathrm{EI}=$ End ileostomy; IRA = Ileorectal anastomosis; IPAA = lleal pouch-anal anastomosis *40 sjúklingar höfðu El og endabarmur fjarlægður, 4 höfðu El en endaparmsstúfur var skilinn eftir

*26 höfðu IPAA og 2 höfðu IPAA og loop ileostomiu pegar rannsókn var gerð

106 sjúklingar fengu senda spurningalista, 49 karlar og 57 konur. Svör bárust frá 83 (78\%), 45 körlum (54\%) og 38 konum (46\%). Meðalaldur við aðgerð var 45 ár (10-91 ár) hjá hópnum í heild. Fjörutíu og fjórir (53\%) höfðu garnarauf (EI, end ileostomy) 28 (34\%) innri garnapoka (IPAA, ileal pouch anal anastomosis) og 11 (13\%) tengingu mjógirnis í endaparm (IRA, ileorectal anastomosis). Мeðalaldur hvers hóps við aðgerð og pegar spurningalista var svarað árið 2011 má sjá í töflu I.

\section{Starfrænar niðurstöður}

Áttatíu og einn sjúklingur svaraði starfræna listanum, að hluta eða í heild, 45 karlar (55\%) og 36 konur (45\%). Meðal sjúklinga par sem endaparmur var fjarlægður $(n=68)$ lýstu $37 \%$ svarenda $(23 / 63)$ breytingum á pvaglátum og 46\% (29/63) á kynlífi eftir aðgerð. Meðal peirra sem lýstu breytingum á pvaglátum áttu 61\% (14/23) erfitt með að hefja pvaglát, 65\% (15/23) áttu erfitt með að tæma blöðru, 35\% (8/23) lýstu áreynsluleka, pvaglátspörf var horfin hjá $17 \%(4 / 23)$ og 13\% (3/23) purftu að ýta á pvagblöðru til að tæma. Meðal karlmanna (17 einstaklingar) lýstu 65\% (11/17) minnkaðri stinningu en enginn lýsti pví að stinning hefði minnkað öðrum megin (limur harðni öðrum megin en sé linur hinum megin) eða horfið og 35\% (6/17) lýstu breytingu á sáđlátum en enginn lýsti pví að sáðlát hefðu horfið. Meðal kvenna (12 einstaklingar) lýstu 67\% (8/12) aukinni útferð, 42\% (5/12) lýstu tíðari leggangasýkingum, $50 \%$ (6/12) lýstu verkjum við samfarir, 50\% (6/12) lýstu minnkaðri tilfinningu í leggöngum, 25\% (3/12) fannst stinning hafa horfið og 75\% (9/12) fannst hún hafa minnkað. Fjórir sjúklingar lýstu breytingu á kynlífi til hins betra. Sjúklingar með innri garnapoka svöruðu spurningum um hægðavenjur og tíðni hægðalosunar (mynd 2). Sjötíu og fimm prósent (18/24) lýstu hægðaleka en hann var vægur samkvæmt Wexner-skala í 83\% (15/18) tilvika (aldrei eða sjaldan leki á formuðum hægðum). Prjátíu og prjú prósent $(8 / 24)$ lýstu erfiðleikum við hægðalosun, pað er að purftu að rembast til að losa hægðir; tveir purftu par að auki að nota fingur til að losa um hægðir.

Sjúklingar með garnarauf svöruðu spurningum tengdum henni. Nítján prósent (7/37) svarenda sögðu staðsetningu garnaraufarinnar geta verið betri. Tuttugu og eitt prósent svarenda (8/38) sögðu lögun garnaraufarinnar geta verið betri. Nítján prósent (7/37) höfðu kviðslit við garnarauf og höfðu 86\% (6/7) peirra farið í aðgerð vegna pess. Blæðing frá stómíu var nokkuð algengt vandamál og höfðu 26\% (10/38) svarenda orðið fyrir pví. Átján prósent (7/38) lýstu vandamálum í tengslum við poka eða plötu. Ber pá helst að nefna leka undir plötu, erfiðleika við að stilla plötu á stómíu og að límingin væri ekki nógu góð. Önnur vandamál á borð við pað að svitna undan plötunni, purfa að klippa hana til par sem hún næði yfir nafla og áhrif staðsetningar garnaraufar á buxnaval og/eða beltanotkun voru einnig nefnd. Húðvandamál í kring um garnarauf voru algeng og sögðust 39\% (15/38) svarenda eiga í húðvanda. Helstu vandamál sem voru nefnd voru roði, kláði, erting, blæðing, sáramyndun og litabreyting húðar.

Fjarvera frá vinnu vegna veikinda og aðgerða var einnig könnuð og reyndist meirihluti svarenda (76\% eða 47/62) kominn til vinnu innan 6 mánaða. Einstaklingum var einnig gefinn kostur á að skrifa athugasemdir. Pónokkrum (7 einstaklingum) fannst að ónógar upplýsingar væru veittar í ferlinu og í kringum aðgerðir, einnig voru nokkrir (5 einstaklingar) sem hefðu viljað eiga kost á aðgerð fyrr í sjúkdómsferlinu. Fleiri gera athugasemd við eftirlit og finnst skortur á pví (6 einstaklingar). Fáir minntust á endurteknar sýkingar og niðurgang sem vandamál (3 einstaklingar). Mikil ánægja er með jafningjafræðslu og pjónustu stómahjúkrunarfræðinga.

\section{SF-36-niðurstöður}

83 sjúklingar svöruðu SF-36 spurningalistanum, 45 karlar (54\%) og 38 konur (46\%). Pegar hópurinn í heild var skoðaður var ekki að sjá mikinn mun á lífsgæðum sjúklinganna borið saman við almennt bandarískt pýði (mynd 3). Ef skoðaður er kynbundinn munur virtust konur meta líkamleg lífsgæði heldur minni en karlmenn (mynd 4). Pegar lífsgæði voru skoðuð miðað við tegund aðgerðar

Tíôni hægôalosunar aô degi og nóttu

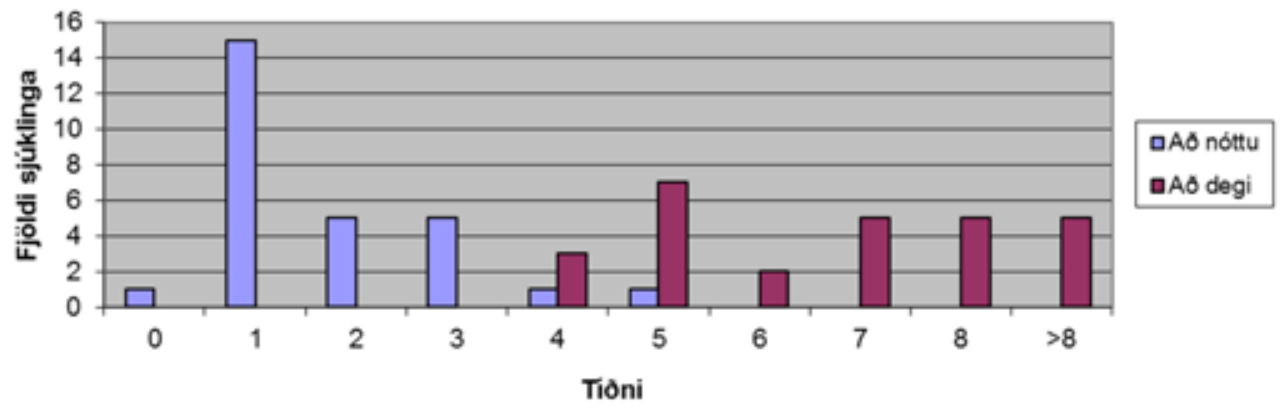

Mynd 2. Myndin sýnir tíðni hægðalosunar sjúklinga með innri garnapoka (IPAA, Ileal pouch-anal anastomosis) að degi og að nóttu til. Meirihluti svarenda $(n=25)$ hafð̇i hægðir 0-1x að nóttu til en allir svarendur höfðu hægð̇ir $4 x$ eða oftar að degi til. 
kom í ljós að par ekki var mikill munur. Lífsgæði peirra sem voru með garnarauf og peirra sem höfðu innri garnapoka voru mjög svipuð (mynd 5). Pegar lífsgæði voru skoðuð út frá aldri mátti einnig sjá að ekki var mikill munur á lífsgæðum rannsóknarhóps samanborið við almennt bandarískt pýði að undanskildum 45-54 ára aldurshópnum. Sá hópur mat andleg lífsgæði sín einu staðalfráviki undir almennu pýði.

\section{EORTC-niðurstöður}

80 sjúklingar svöruðu EORTC-spurningalistanum, 44 karlar (55\%) og 36 konur (45\%). Almennt höfðu pátttakendur ekki miklar áhyggjur af heilsu sinni, líkamsímynd eða pyngd eins og sjá má á töflu II og III. Í heildina höfðu sjúklingar lítil einkenni og á pað við um öll einkenni sem spurt var um (33 stig = dálítil einkenni). Pau einkenni sem skoruðu hæst hjá hópnum í heild voru vindgangur og húðvandamál. Konur höfðu minni áhuga á kynlífi en karlar (67 stig og 33 stig). Af peim 36 konum sem svöruðu EORTC-spurningalistunum svöruðu 24 (67\%) spurningum um áhuga á kynlífi og 21 (58\%) spurningum um verki við samfarir. Svarhlutfall við kynlífstengdum spurningum var mun betra meðal karla en $98 \%$ (43/44) peirra svöruðu spurningum um áhuga á kynlífi og stinningarvanda. Eins og sjá má á töflu II var ekki marktækur munur einkenna milli peirra sem hafa garnarauf ( 24 karlar og 20 konur) og peirra sem ekki hafa garnarauf (20 karlar og 16 konur). Pó virtist vera aukinn vindgangur meðal garnaraufarsjúklinga en aukin tíðni hægðalosunar hjá peim sem ekki voru með garnarauf (tafla II). Auk pess voru garnaraufarsjúklingar með meiri verki við samfarir og stinningarvanda (tafla II). Konur með garnarauf höfðu minni áhuga á kynlífi en konur með innri garnatengingu (IRA og IPAA) Pegar skoðað var út frá aldurshópum var ekki hægt að sjá marktækan mun á milli hópa (tafla III), nema tíðni hægðalosunar milli hópanna 35-44 ára og 65-74 ára.

\section{Umræður}

Samkvæmt niðurstöðum starfræna spurningalistans var nokkuð hátt hlutfall sjúklinga sem lýsir breytingum á pvaglátum, kynlífi og hægðavenjum eftir aðgerð. Hins vegar bentu niðurstöður SF-36v2 spurningalistans til pess að lífsgæði sjúklinga sem farið höfðu í ristilbrottnám vegna sáraristilbólgu væru svipuð og meðal bandarísks almennings, prátt fyrir ýmis líkamleg einkenni. Niðurstöður EORTC-spurningalistans bentu til pess að pátttakendur hefðu almennt ekki miklar áhyggjur af heilsu sinni eða líkamsímynd. Auk pess höfðu sjúklingar almennt lítil einkenni samkvæmt peim spurninga-

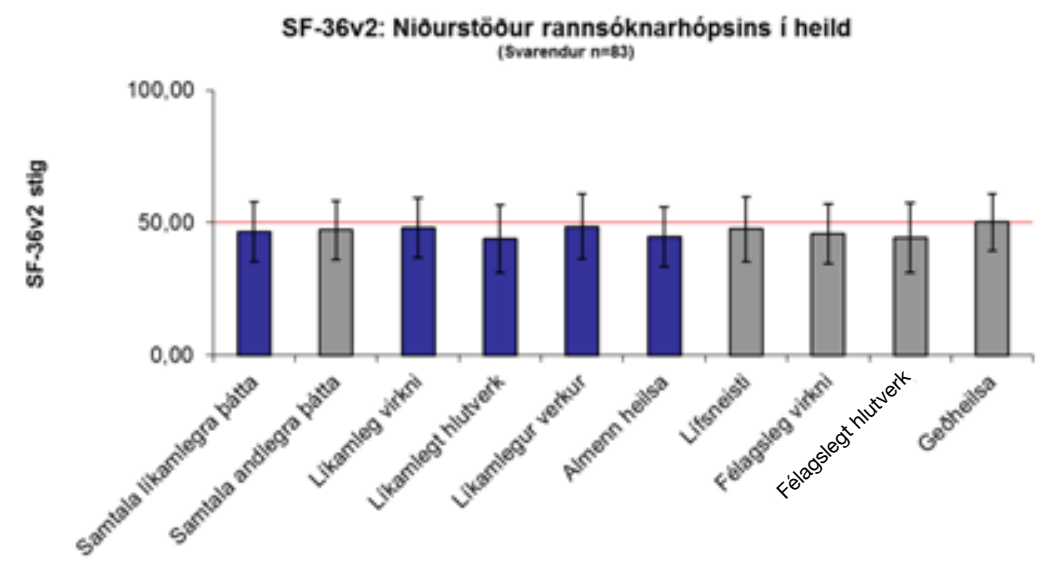

Mynd 3. Rauða línan táknar meðalstig almenns pýđis (50, staðalfrávik 10). Fyrstu tvær súlurnar vinstra megin sýna samtölur líkamlegra (blá) og andlegra (grá) pátta. Súlurnar átta til hægri við pær sýna pá undirflokka líkamlegra (bláar súlur) og andlegra (gráar súlur) pátta sem spurt var út í. Samtala líkamlegra pátta (Physical Component Summary) á meðal sjúklinga var að meðaltali 46,64 (1 staðalfrávik=11,25) samanborið við 50 (1 staðalfrávik=10) hjá almennu bandarísku pýdi (rauða línan). Samtala andlegra pátta (Mental Component Summary) (gráar súlur) meðal sjúklinga var að meðaltali 47,28 (1 staðalfrávik 11,15) samanborið við 50 (1 staðalfrávik 10) hjá almennu bandarísku pýdi.

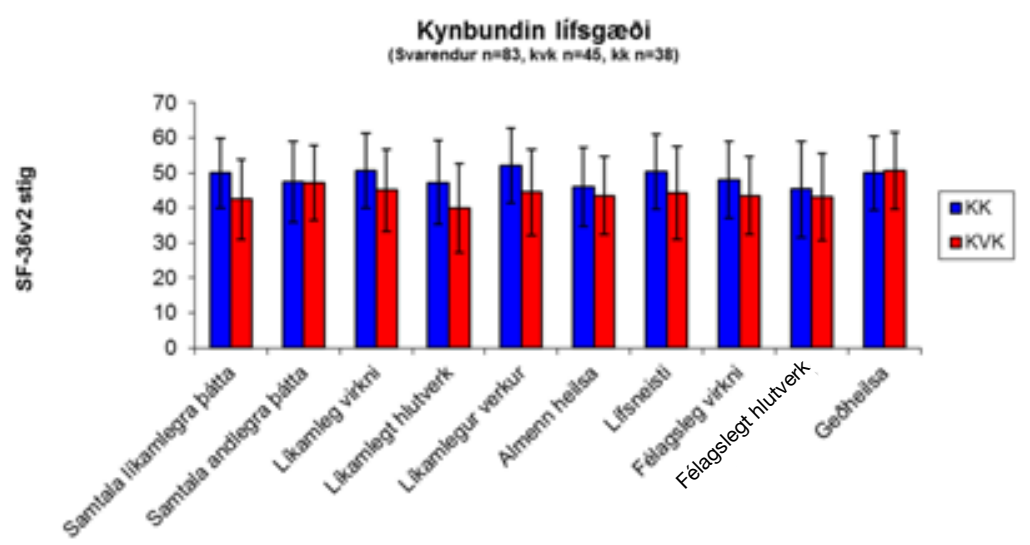

Mynd 4. Degar niðurstöður eru skoðaðar út frá kynjum má sjá að konur meta líkamleg lífsgæði heldur minni en karlmenn $(42,39$ á móti 49,95) en munurinn nær pó ekki einu staðalfráviki.

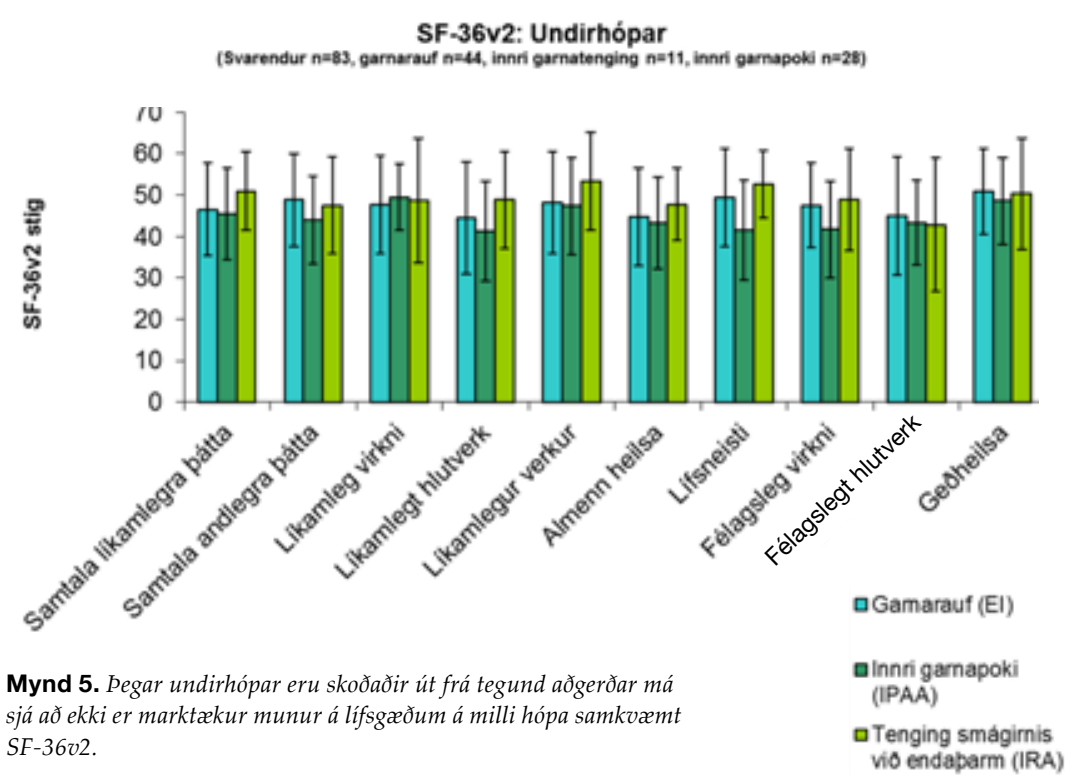


Tafla II. EORTC-niðurstöður (miðgildi (interquartile range)). Tölugildin sem gefin eru eru milli 0 og 100. Fyrir lifsgæði i almenna lifsgæða- og virkniskalanum pýðir hærra gildi meiri lifsgæði. Fyrir einkennaskalana pýðir hærra gildi verri/meiri einkenni. Í pessari töflu eru niðurstöður birtar fyrir hópinn í heild og eftir kyni og tegund aðgerðar.

\begin{tabular}{|c|c|c|c|c|c|}
\hline Virkniskali & Allir $(n=80)$ & $\mathrm{KVK}(\mathrm{n}=36)$ & $\mathrm{KK}(\mathrm{n}=44)$ & Garnarauf $(n=44)$ & Án garnaraufar $(n=36)$ \\
\hline Líkamsímynd & $88(50-100)$ & $88(67-100)$ & $88(44-100)$ & $88(44-100)$ & $88(67-100)$ \\
\hline Kvíði & $67(67-100)$ & $67(67-100)$ & $67(33-100)$ & $67(67-100)$ & $67(33-100)$ \\
\hline Pyngd & $100(100)$ & $100(67-100)$ & $67(67-100)$ & $67(67-100)$ & $100(67-100)$ \\
\hline Kynlíf kk & $33(0-67)$ & $x$ & $33(0-67)$ & $33(17-33)$ & $33(0-67)$ \\
\hline Kynlíf kvk & $67(33-75)$ & $67(33-75)$ & $x$ & $67(67-100)$ & $67(33-67)$ \\
\hline \multicolumn{6}{|l|}{ Einkennaskali } \\
\hline Tíðni pvagláta & $17(0-33)$ & $17(0-33)$ & $17(0-33)$ & $17(0-33)$ & $17(0-33)$ \\
\hline Blóð og slím í hægðum & $0(0)$ & $0(0-17)$ & $0(0-8)$ & $0(0)$ & $8(0-21)$ \\
\hline Tíðni hægðalosunar & $17(0-50)$ & $33(0-67)$ & $17(0-42)$ & $0(0-17)$ & $50(33-67)$ \\
\hline Pvagleki & $0(0)$ & $0(0)$ & $0(0)$ & $0(0)$ & $0(0)$ \\
\hline Sársauki við pvaglát & $0(0)$ & $0(0)$ & $0(0)$ & $0(0)$ & $0(0)$ \\
\hline Kviðverkir & $0(0-33)$ & $0(0-33)$ & $0(0-33)$ & $0(0-33)$ & $33(0-33)$ \\
\hline Verkir í rasskinnum & $0(0-33)$ & $17(0-33)$ & $0(0-33)$ & $0(0)$ & $33(0-33)$ \\
\hline Kviðpensla & $0(0-33)$ & $33(0-33)$ & $0(0-33)$ & $0(0-33)$ & $33(0-33)$ \\
\hline Purr munnur & $0(0-33)$ & $0(0-42)$ & $0(0-33)$ & $0(0-33)$ & $0(0-33)$ \\
\hline Hárlos & $0(0)$ & $0(0)$ & $0(0)$ & $0(0)$ & $0(0)$ \\
\hline Bragð̌skyn & $0(0)$ & $0(0)$ & $0(0)$ & $0(0)$ & $0(0)$ \\
\hline Vindlosun & $33(0-33)$ & $33(0-67)$ & $33(0-33)$ & $33(33-67)$ & $0(0)$ \\
\hline Hægðaleki & $0(0-33)$ & $0(0-33)$ & $0(0-33)$ & $0(0-33)$ & $0(0-33)$ \\
\hline Húðeymsli & $33(0-33)$ & $33(33-67)$ & $33(0-33)$ & $33(33)$ & $33(0-33)$ \\
\hline Blygðun & $0(0-33)$ & $0(0-33)$ & $0(0-33)$ & $0(0-33)$ & $33(0-33)$ \\
\hline Umönnun garnaraufar & $0(0)$ & $0(0)$ & $0(0)$ & $0(0)$ & $x$ \\
\hline Risvandamál & $0(0-33)$ & $x$ & $0(0-33)$ & $33(0-50)$ & $0(0-33)$ \\
\hline Verkir við samfarir & $0(0-33)$ & $0(0-33)$ & $x$ & $33(0-67)$ & $0(0-25)$ \\
\hline
\end{tabular}

KVK=kvenkyn; KK=karlkyn; EORTC = European Organization for Research and Treatment of Cancer. $x$ = á ekki við.

lista og ekki kom fram marktækur munur á milli peirra sem höfðu garnarauf og hinna. Við teljum pví óhætt að draga pá ályktun að prátt fyrir að algengt sé að breytingar verði á líkamsstarfsemi eftir aðgerð sé pað ekki í peim mæli að pað valdi fólki ama í daglegu lífi.

Niðurstöður okkar úr starfræna listanum sýndu að hátt hlutfall sjúklinga með innri garnapoka lýsti einhverjum hægðaleka. Í erlendri rannsókn sem mat starfræna útkomu innri garnapoka meðal 191 sjúklinga með sáraristilbólgu kom í ljós að 68\% sjúklinga hafði hægðir 8 sinnum á dag en $29 \%$ peirra sjaldnar en 6 sinnum á dag. Auk pess lýstu 6,5\% sjúklinganna viðvarandi hægðaleka en tíðni hægðaleka var hærri á næturnar, eða 39\%. ${ }^{20}$ Önnur rannsókn meðal finnskra sjúklinga sýndi fram á hægðaleka að nóttu til í 32\% tilvika. ${ }^{21}$ Okkar hlutfall er töluvert hærra miðað við fyrrgreindar rannsóknir. Hluti ástæðunnar gæti verið að ekki voru notaðir sömu spurningalistar. Starfræni listinn okkar er ítarlegur og var hannaður aðallega til að meta fylgikvilla aðgerðar frekar en ávinning og spyr pví nákvæmlega út í fyrrgreinda pætti.

Um priðjungur lýsti breytingum á pvaglátum. Рað er erfitt að bera pessar niðurstöður saman við erlendar rannsóknir par sem fæstar peirra fjalla sérstaklega um breytingar á pvaglátum.
Fjörutíu prósent okkar sjúklinga lýsti breytingum á kynlífi til hins verra. Niðurstöðum erlendra rannsókna varðandi áhrif á kynlíf (sexual function) ber ekki alltaf saman en ljóst er að áhrifin geta verið bæði neikvæð og jákvæð. Rannsókn meðal 59 sjúklinga með sáraristilbólgu sem fóru í innri garnapokaaðgerð mat sérstaklega áhrif aðgerðar á kynlíf peirra. Samkvæmt niðurstöðum hafði aðgerð ekki marktæk áhrif á kynlíf karlmanna en bætti kynlíf kvenna svo um munaði.22 Niðurstöður japanskrar rannsóknar bendir hins vegar til pess að aðgerðir sem pessi geti haft töluverð neikvæð áhrif á kynlíf sjúklinga eftir aðgerð. Nítján af 60 sjúklingum (31\%) lýstu neikvæðum áhrifum á kynlíf, 24\% karlmanna og $38 \%$ kvenna. ${ }^{23}$ Pessar niðurstöður samræmast frekar niðurstöðum okkar. Engin kona í rannsókn okkar lýsti pví að kynlíf væri betra eftir aðgerðina. Раð að rannsóknarniðurstöður varðandi kynlíf séu svo ólíkar vekur spurningar um hvort spurningalistar pess efnis séu nógu góðir.

Rannsóknir hafa staðfest að lífsgæði sjúklinga með virkan sjúkdóm eru minni en meðal almenns pýðis. Lífsgæði sjúklinga sem svara lyfjameðferð samsvara hins vegar almennu pýði. ${ }^{24}$ Pátttakendur í rannsókn okkar, bæði konur og karlar, höfðu lífsgæði í samræmi við almennt bandarískt pýði samkvæmt SF-36v2-spurninga- 
Tafla III. EORTC-niðurstöður út frá aldurshópum.

\begin{tabular}{|c|c|c|c|c|c|c|}
\hline Virkniskali & $25-34(n=11)$ & $35-44(n=14)$ & $45-54(n=17)$ & $55-64(n=15)$ & $65-74(n=15)$ & $75-(n=8)$ \\
\hline Líkamsímynd & $67(42-88)$ & $88(39-97)$ & $88(44-100)$ & $88(53-100)$ & $88(58-100)$ & $100(84-100)$ \\
\hline Kvíði & $67(67-100)$ & $67(42-100)$ & $67(33-100)$ & $67(67-100)$ & $100(67-100)$ & $83(67-100)$ \\
\hline Pyngd & $100(100)$ & $100(67-100)$ & $67(33-100)$ & $67(67-100)$ & $100(67-100)$ & $100(67-100)$ \\
\hline Kynlíf kk & $17(0-33)$ & $33(0-33)$ & $33(33-67)$ & $33(0-67)$ & $33(33-50)$ & $33(33)$ \\
\hline Kynlíf kvk & $67(0-33)$ & $67(67)$ & $67(50-100)$ & $50(33-67)$ & $67(58-75)$ & $100(100)$ \\
\hline \multicolumn{7}{|l|}{ Einkennaskali } \\
\hline Tíoni pvagláta & $17(0-25)$ & $25(0-50)$ & $0(0-33)$ & $17(0-17)$ & $8(0-17)$ & $25(0-50)$ \\
\hline Blóð og slím í hægðum & $0(0-25)$ & $0(0-13)$ & $0(0-21)$ & $0(0)$ & $0(0)$ & $0(0-21)$ \\
\hline Tíðni hægðalosunar & $33(8-58)$ & $50(17-67)$ & $33(0-38)$ & $0(0-46)$ & $0(0-17)$ & $33(8-50)$ \\
\hline Pvagleki & $0(0)$ & $0(0)$ & $0(0-33)$ & $0(0)$ & $0(0)$ & $0(0)$ \\
\hline Sársauki við pvaglát & $0(0)$ & $0(0)$ & $0(0)$ & $0(0)$ & $0(0)$ & $0(0)$ \\
\hline Kviðverkur & $0(0-33)$ & $33(0-33)$ & $0(0-33)$ & $0(0)$ & $0(0-33)$ & $0(0-33)$ \\
\hline Verkur í rasskinnum & $33(0-33)$ & $33(8-33)$ & $0(0-33)$ & $0(0)$ & $0(0)$ & $17(0-42)$ \\
\hline Kviðpensla & $33(0-50)$ & $33(0-33)$ & $17(0-67)$ & $0(0)$ & $0(0-33)$ & $33(0-33)$ \\
\hline Munnpurrkur & $0(0-33)$ & $0(0-33)$ & $0(0-33)$ & $17(0-67)$ & $0(0-33)$ & $33(0-42)$ \\
\hline Hárlos & $0(0)$ & $0(0)$ & $0(0)$ & $0(0)$ & $0(0)$ & $0(0)$ \\
\hline Bragðskyn & $0(0)$ & $0(0)$ & $0(0)$ & $0(0)$ & $0(0)$ & $0(0)$ \\
\hline Vindlosun & $0(0-33)$ & $0(0-33)$ & $33(0-33)$ & $33(0-67)$ & $33(0-67)$ & $17(0-33)$ \\
\hline Hægðaleki & $0(0-33)$ & $0(0-25)$ & $0(0-33)$ & $0(0-33)$ & $0(0-33)$ & $33(0-33)$ \\
\hline Húđeymsli & $33(0-33)$ & $33(33-67)$ & $33(0-33)$ & $33(33-50)$ & $33(0-33)$ & $33(33-50)$ \\
\hline Blygðun & $33(0-33)$ & $17(0-33)$ & $0(0-33)$ & $0(0-33)$ & $0(0-67)$ & $17(0-33)$ \\
\hline Umönnun garnaraufar & $0(0)$ & $0(0)$ & $0(0)$ & $0(0)$ & $0(0)$ & $17(0-33)$ \\
\hline Risvandamál & $0(0-25)$ & $0(0-33)$ & $0(0-33)$ & $50(0-92)$ & $33(17-50)$ & $0(0)$ \\
\hline Verkir við samfarir & $0(0)$ & $17(8-25)$ & $33(0-33)$ & $17(0-50)$ & $17(8-50)$ & $0(0)$ \\
\hline
\end{tabular}

KVK=kvenkyn; KK=karlkyn; EORTC = European Organization for Research and Treatment of Cancer. $\mathrm{x}=$ á ekki við.

listanum. Pónokkrar rannsóknir hafa metið lífsgæði sjúklinga sem hafa purft að fara í ristilbrottnám vegna sáraristilbólgu. 13,14,16,19,21,25-31 Mun fleiri rannsóknir fjalla um sjúklingahóp með innri garnapoka en garnarauf. Rannsókn Camilleri-Brennan á meðal sjúklinga með garnarauf sýndi fram á lífsgæði sambærileg og meðal almennings. ${ }^{13}$ Líkt og rannsókn okkar gátu tvær erlendar rannsóknir sem báru saman lífsgæði sjúklinga með garnarauf og innri garnapoka ekki sýnt fram á mun á milli hópa. ${ }^{16,25}$ Rannsókn Muir bar saman lífsgæði sjúklingahóps fyrir og eftir aðgerð par sem búinn var til innri garnapoki og sýndi fram á meiri lífsgæði eftir aðgerð. ${ }^{28}$ Í yfirlitsgrein um lífsgæði sjúklinga eftir innri garnapokaaðgerð voru skoðaðar 33 greinar pess efnis og komist að peirri niðurstöðu að lífsgæði pessa sjúklingahóps séu sambærileg og hjá heilbrigðum einstaklingum. ${ }^{26}$ Aldurstengd lífsgæði voru svipuð og meðal almenns pýðis að undanskildum 45-54 ára aldurshópnum sem lá einu staðalfráviki undir almennu pýði. EORTC-niðurstöður fyrir pennan aldurshóp sýndi mild líkamleg einkenni líkt og hjá hinum hópunum. Hins vegar hafði pessi hópur minnstan áhuga á kynlífi og pegar litið var á niðurstöður starfræna listans var nokkuð hátt hlutfall svarenda með neikvæða breytingu á kynlífi í pessum aldurshópi (8 af 24 einstaklingum). Fáir einstaklingar voru í hverj- um aldursflokki (8-17 einstaklingar) og vega niðurstöður hvers sjúklings pungt. Fyrrgreindar rannsóknir hafa ekki sýnt fram á kyn- eða aldursbundinn mun lífsgæða.

Samkvæmt EORTC-spurningalistanum höfðu pátttakendur í rannsókn okkar ekki miklar áhyggjur af heilsu sinni, líkamsímynd eða pyngd. Í heildina höfðu sjúklingar lítil einkenni og enginn marktækur munur milli peirra sem höfðu garnarauf og peirra sem ekki höfðu garnarauf. Konur höfðu minni áhuga á kynlífi en karlar. Hugsanlegt er að pað geti endurspeglast í pví að ristilbrottnámsaðgerð geti haft neikvæð áhrif á kynlíf kvenna í meira mæli en karla eins og kemur fram í okkar rannsókn að konur höfðu meiri einkenni taugaskaða og verki við samfarir líkt og ein rannsókn benti til. ${ }^{23}$ Sýnt var fram á aukin lífsgæði meðal $83 \%$ pátttakenda í rannsókn par sem sjúklingar undirgengust innri garnapokaaðgerð (IPAA). Lífsgæði peirra eftir aðgerð voru nánast eðlileg og einkenni lítil. Pau einkenni sem jukust eftir aðgerð voru aðallega tíðni hægðalosunar. ${ }^{32}$ Önnur rannsókn sýndi engan marktækan mun lífsgæða og einkenna (аð undanskilinni tíðni hægðalosunar) milli sjúklinga sem farið höfðu í innri garnapokaaðgerð og sjúklinga á lyfjameðferð. ${ }^{19}$ Af pessu má draga pær ályktanir að einkenni sjúklinga batna til muna eftir aðgerð en 
sömuleiðis geta einkenni verið lítil á lyfjameðferð ef sjúkdómurinn svarar henni.

Styrkur pessarar rannsóknar er að hún byggir á gögnum heillar pjóðar um sjúklinga með sáraristilbólgu frá umræddu tímabili. Pessi sjúklingahópur leitar á sjúkrahús ef eitthvað alvarlegt kemur upp á og pví er auðvelt að fylgja peim eftir. Svarhlutfall var hátt (78\%). Ekki er hægt að fullyrða um hvort lífsgæði peirra sem ekki svöruðu séu minni en hinna sem svöruðu. Petta gæti hafa skekkt niðurstöðurnar að einhverju leyti.

Niðurstöður SF-36v2-listans voru bornar saman við almennt bandarískt pýði sem kann að vera ólíkt almennu íslensku pýði. Pað hefði styrkt rannsóknina enn frekar að hafa samanburðarhóp, með sjúklingum með sáraristilbólgu á lyfjameðferð sem ekki hafa farið í aðgerð. Hugsanlega væri réttara að spyrja hvort lífsgæði peirra séu meiri en pau voru fyrir aðgerð.

Раð að við höfum ekki rannsakað með tilliti til truflandi pátta veikir rannsóknina pví ekki er hægt að leiðrétta fyrir peim. Hugsanlegt er að pættir eins og offita, reykingar, áfengisneysla og aðrir sjúkdómar hafi áhrif á niðurstöður.

Starfræni listinn sem notaður var í pessari rannsókn er búinn til af rannsóknaraðilum og par er ekki um staðlaðan lista að ræða.

Prátt fyrir hátt svarhlutfall (78\%) dregur pað úr öryggi niðurstaðna að pað svöruðu ekki allir og hve lítið pýðið er. Hugsanlegt er að peir sem eru með lítil einkenni hafi takmarkaðan áhuga á að taka pátt. Ef til vill taka einstaklingar sem glíma við andleg vandamál síður pátt. Aldraðir einstaklingar eiga hugsanlega erfitt með að svara spurningunum (til dæmis elliglöp, sjóndepra).

Ákveðin bjögun liggur í sjúklingavali par sem einungis peir sem voru á lífi gátu tekið pátt. Hugsanlegt er að stöðluðu spurningalistarnir sjálfir séu ekki nógu góðir til rannsóknar á pessum sjúklingahópi par sem peir voru hannaðir fyrir krabbameinssjúklinga.

Í rannsókn okkar hefur komið í ljós að hluti sjúklinga óskar eftir bættri fræðslu fyrir aðgerð og aukinni eftirfylgd eftir aðgerð. Hvort tveggja er nokkuð sem auðvelt er að bæta. Fræðsla sjúklinga um okkar niðurstöður getur hjálpað peim við ákvarðanatöku fyrir aðgerð.

Segja má að algengt sé að breytingar verði á pvaglátum og kynlífi eftir aðgerð pegar endaparmur er fjarlægður. Hægðaleki hjá peim sem höfðu innri garnapoka var mun algengari en búist var við. Pó var ekki sýnt fram á marktækan mun á lífsgæðum peirra sem höfðu farið í aðgerð og almenns pýðis. •ar að auki var ekki marktækur munur á lífsgæðum peirra sem voru með garnarauf og hinna sem höfðu innri garnatengingu (IRA og IPAA). Niðurstöður rannsóknarinnar eru pví mikilvægar pegar verið er að upplýsa sjúklinga um aðgerðarmöguleika. Við getum óhrædd ráðlagt sjúklingum að fara í ristilbrottnám með garnarauf, en pað er heldur ekkert sem mælir gegn pví að framkvæma innri garnatengingu hvað lífsgæði varðar ef sjúklingur vill pað frekar. 


\section{Heimildir}

1. Bjornsson S. Inflammatory bowel disease in Iceland during a 30-year period, 1950-1979. Scand J Gastroenterol Suppl 1989; 170: 47-9; discussion 50-5.

2. Bjornsson $\mathrm{S}$, Johannsson $\mathrm{JH}$, Oddsson E. Inflammatory bowel disease in Iceland, 1980-89. A retrospective nationwide epidemiologic study. Scand J Gastroenterol 1998; 33: 71-7.

3. Bjornsson S, Johannsson JH. Inflammatory bowel disease in Iceland, 1990-1994: a prospective, nationwide, epidemiological study. Eur J Gastroenterol Hepatol 2000; 12: 31-8.

4. Bjornsson S, Tryggvason FP, Jonasson JG, Cariglia N, Örvar K, Kristjánsdóttir S, et al. Incidence of inflammatory bowel disease in Iceland 1995 - 2009. A nationwide population-based study. Scand J Gastroenterol 2015; 50: 1368-75.

5. Andersson P, Soderholm JD. Surgery in ulcerative colitis: indication and timing. Dig Dis 2009; 27 : 335-40.

6. Meier J, Sturm A. Current treatment of ulcerative colitis. World J Gastroenterol 2011;17: 3204-12.

7. Thorne K, Alrubaiy L, Akbari A, Samuel DG, MorrisonRees S, Roberts SE. Colectomy rates in patients with ulcerative colitis following treatment with infliximab or ciclosporin: a systematic literature review. Eur J Gastroenterol Hepatol 2016;28:369-82.

8. Frolkis AD, Dykeman J, Negron ME, et al. Risk of surgery for inflammatory bowel diseases has decreased over time: a systematic review and meta-analysis of population-based studies. Gastroenterol 2013;145:996-1006.

9. Turnbull RB, Jr. Surgical treatment of ulcerative colitis: early results after colectomy and low ileorectal anastomosis. Dis Colon Rectum 1959;2:260-3.

10. Parks AG, Nicholls RJ. Proctocolectomy without ileostomy for ulcerative colitis. BMJ 1978; 2: 85-8.

11. Danese S, Fiocchi C. Ulcerative colitis. New Engl J Med 2011; 365: 1713-25.

12. Ko Y, Butcher R, Leong RW. Epidemiological studies of migration and environmental risk factors in the inflammatory bowel diseases. World J Gastroenterol 2014 20: $1238-47$.

13. Camilleri-Brennan J, Steele RJ. Objective assessment of quality of life following panproctocolectomy and ileostomy for ulcerative colitis. Ann R Coll Surg Engl 2001; 83: $321-4$.
14. Martin A, Dinca M, Leone L, et al. Quality of life after proctocolectomy and ileo-anal anastomosis for severe ulcerative colitis. Am J Gastroenterol 1998; 93: 166-9.

15. Berndtsson I, Oresland T. Quality of life before and after proctocolectomy and IPAA in patients with ulcerative proctocolitis--a prospective study. Colorectal Dis 2003; 5: 173-9.

16. Kuruvilla K, Osler T, Hyman NH. A comparison of the quality of life of ulcerative colitis patients after IPAA vs ileostomy. Dis Colon Rectum 2012; 55: 1131-7.

17. Jimmo B, Hyman NH. Is ileal pouch-anal anastomosis really the procedure of choice for patients with ulcerative colitis? Dis Colon Rectum 1998; 41: 41-5.

18. Whistance RN, Conroy T, Chie W, Costantini A, Sezer O, Koller M, et al. Clinical and psychometric validation of the EORTC QLQ-CR29 questionnaire module to assess health-related quality of life in patients with colorectal cancer. Eur J Cancer 2009; 45: 3017-26.

19. Meijs S, Gardenbroek TJ, Sprangers MA, Bemelman WA, Buskens CJ, D'Haens GR, et al. Health-related quality of life and disability in patients with ulcerative colitis and proctocolectomy with ileoanal pouch versus treatment with anti-TNF agents. J Crohns Colitis 2014; 8: 686-92.

20. de Buck van Overstraeten A, Wolthuis AM, Vermeire $S$, Van Assche G, Laenen A, Ferrante M, et al. Long-term functional outcome after ileal pouch anal anastomosis in 191 patients with ulcerative colitis. J Crohns Colitis 2014; 8: 1261-6.

21. Tiainen J, Matikainen M. Health-related quality of life after ileal J-pouch-anal anastomosis for ulcerative colitis: long-term results. Scand J Gastroenterol 1999;34:601-5.

22. Davies RJ, O'Connor BI, Victor C, MacRae HM, Cohen Z, McLeod RS. A prospective evaluation of sexual function and quality of life after ileal pouch-anal anastomosis. Dis Colon Rectum 2008; 51: 1032-5.

23. Yoshida K, Araki T, Uchida K, Okita Y, Fujikawa H, Inoue $\mathrm{M}$, et al. Sexual activity after ileal pouch-anal anastomosis in Japanese patients with ulcerative colitis. Surg Today 2014; 44: 73-9.

24. Hodgkins P, Yen L, Yarlas A, Karlstadt R, Solomon D, Kane S. Impact of MMX(R) mesalamine on improvement and maintenance of health-related quality of life in patients with ulcerative colitis. Inflamm Bowel Dis 2013; 19: 386-96.
25. Berndtsson I, Oresland T. Quality of life before and after proctocolectomy and IPAA in patients with ulcerative proctocolitis--a prospective study. Colorectal Dis 2003; 5 173-9.

26. Heikens JT, de Vries J, van Laarhoven CJ. Quality of life, health-related quality of life and health status in patients having restorative proctocolectomy with ileal pouch-anal anastomosis for ulcerative colitis: a systematic review. Colorectal Dis 2012; 14:536-44.

27. Malik BA, Gibbons K, Spady D, Lees G, Otley A, Huynh HQ. Health-related quality of life in pediatric ulcerative colitis patients on conventional medical treatment compared to those after restorative proctocolectomy. Int J Colorect Dis 2013; 28: 325-33.

28. Muir AJ, Edwards LJ, Sanders LL, Bollinger RR, Koruda MJ, Bachwich DR, et al. A prospective evaluation of health-related quality of life after ileal pouch anal anastomosis for ulcerative colitis. Am J Gastroenterol 2001; 96 1480-5.

29. Robb BW, Pritts TA, Warner BW. Health-related quality of life after ileal pouch anal anastomosis for ulcerative colitis: right answer-wrong question. Gastroenterol 2002; 122 1180-1.

30. Scarpa M, Angriman I, Ruffolo C, Ferronato A, Polese L, Barollo M, et al. Health-related quality of life after restorative proctocolectomy for ulcerative colitis: long-term results. World J Surg 2004; 28: 124-9.

31. Uchida K, Kawamata A, Hashimoto K, Inoue M, Otake K, Koike $Y$, et al. Self-reported assessment of health-related quality of life in children who underwent restorative proctocolectomy with ileal J-pouch anal anastomosis for ulcerative colitis. Pediatr Surg Int 2013; 29: 287-91.

32. Willis S, Lorken M, Holzl F, Fackeldey V, Schumpelick V. [Functional results and quality of life after proctocolectomy and ileal J-pouch-anal anastomosis for ulcerative colitis]. Zentralbl Chir 2003; 128: 663-8.

\section{ENGLISH SUMMARY}

\section{Quality of Life after colectomy due to ulcerative colitis}

Katrín Guðlaugsdóttir ${ }^{1}$, Elsa B. Valsdóttir ${ }^{1,2}$, Tryggvi B. Stefánsson ${ }^{1}$

Introduction: A significant proportion of patients with ulcerative colitis (UC) undergo colectomy. The aim was to assess the quality of life (QOL) of these patients.

Material and methods: All patients with UC who underwent colectomy at The National University Hospital of Iceland or Akureyri Hospital 1995-2009 were included. 106 patients received three questionnaires. SF-36v2 and EORTC are standardised QOL-questionnaires. The third contained functional questions designed by the researchers.

Results: Eighty-three patients replied (78\%), 45 men (54\%) and 38 women (46\%). Average age at operation was 45 years (10-91 years). Forty-four (53\%) had ileostomy, 28 (34\%) ileal pouch-anal anastomosis (IPAA) and 11 (13\%) ileorectal anastomosis. Among patients who had the rectum removed $37 \%$ described changes in urinary habits and $46 \%$ in sexual life after surgery. Among patients with IPAA $75 \%$ admitted to faecal incontinence but this was mild according to Wexner's scale in $83 \%$ of the cases. According to SF-36v2 there was no significant difference in the QOL of colectomy patients compared to the general population. Patients generally felt good about their health, body image and weight and had mild symptoms according to EORTC QLQ-CR29.

Conclusions: Urinary habits and sexual life were commonly affected after rectal removal. Faecal incontinence among IPAA-patients was much more common than expected. There was not much difference in quality of life compared to the general population. The results of the study are important for patient education and may aid them in their decision making since removing the colon or having a stoma does not seem to affect quality of life. 